\title{
Implications of Long Non-Coding RNAs in Age-Altered Proteostasis
}

\author{
Cristina-Sorina Catana ${ }^{1}$, Catalina-Angela Crișan², Dana Opre ${ }^{3}$, Ioana Berindan-Neagoe ${ }^{4,5,6 *}$ \\ ${ }^{1}$ Department of Medical Biochemistry, "Iuliu Haţieganu” University of Medicine and Pharmacy Cluj-Napoca, \\ Cluj-Napoca, Romania. ${ }^{2}$ Department of Neurosciences, "Iuliu Haţieganu" University of Medicine and Pharmacy \\ Cluj-Napoca, Cluj-Napoca, Romania. ${ }^{3}$ Department of Psychology, Babeș-Bolyai University, Cluj-Napoca, \\ Romania. ${ }^{4}$ MEDFUTURE - Research Center for Advanced Medicine, Cluj-Napoca, Romania. ${ }^{5}$ Research Center \\ for Functional Genomics, Biomedicine and Translational Medicine, Institute of Doctoral Studies, "Iuliu \\ Hatieganu" University of Medicine and Pharmacy, Cluj-Napoca, Romania. ${ }^{6}$ Department of Experimental \\ Pathology, "Prof. Dr. Ion Chiricuta" Oncology Institute, Cluj-Napoca, Romania.
}

[Received June 20, 2019; Revised August 8, 2019; Accepted August 14, 2019]

\begin{abstract}
This review aims to summarize the current knowledge on how IncRNAs are influencing aging and cancer metabolism. Recent research has shown that senescent cells re-enter cell-cycle depending on intrinsic or extrinsic factors, thus restoring tissue homeostasis in response to age-related diseases (ARDs). Furthermore, maintaining proteostasis or cellular protein homeostasis requires a correct quality control (QC) of protein synthesis, folding, conformational stability, and degradation. Long non-coding RNAs (IncRNAs), transcripts longer than 200 nucleotides, regulate gene expression through RNA-binding protein (RBP) interaction. Their association is linked to aging, an event of proteostasis collapse. The current review examines approach es that lead to recognition of senescence-associated IncRNAs, current methodologies, potential challenges that arise from studying these molecules, and their crucial implications in clinical practice.
\end{abstract}

Key words: lnc RNA, cancer metabolism, age-related diseases, proteostasis, HOTAIR

Age-associated diseases such as cancer, cardiovascular diseases, obesity, neurodegenerative disorders, sarcopenia and several other conditions are dictated by distinct adjustments of gene expression programs that underlie aging. Recent research indicates that through examining the modifying factors of intrinsic appearance of senescent cells we could genetically program and determine their re-entry into the cellular cycle. Thereupon, in the future, senescent cells might be programmed to get involved in the treatment of cancer and aging-related diseases [1].
Aging phenotype is represented by expanded cellular senescence, reduction of stem cell population, altered proteostasis (which activates the inflammasome a multiprotein oligomer responsible for inflammation), change in intercellular communication and loss of telomere function $[2,3]$.

Maintaining cellular protein homeostasis, or proteostasis, requires correct quality control (QC) of protein-related processes: synthesis, folding, conformational stability, degradation. A complicated and flexible proteostasis network (PN) parallels these processes with molecular chaperones and their QC

*Correspondence should be addressed to: Dr. Ioana Berindan-Neagoe, MEDFUTURE - Research Center for Advanced Medicine, 400012 Cluj-Napoca, Romania. Email: ioananeagoe29@gmail.com.

Copyright: (C) 2019 Catana C. et al. This is an open-access article distributed under the terms of the Creative Commons Attribution License, which permits unrestricted use, distribution, and reproduction in any medium, provided the original author and source are credited. 
regulators thus avoiding age-associated proteinopathies included in ARDs [4].

These mechanisms are governed by proteins that bind RNA, DNA, as well as a diversity of long non-coding RNAs (lncRNAs), long nuclear RNAs greater than 200 nucleotides, and microRNAs (miRNAs), small noncoding RNA molecules with a length of 20-25 nucleotides that are involved in controlling target gene translation and post-transcriptional modulation of gene expression. The regulatory function of IncRNAs, which are considered powerful epigenetic regulators, has been partially revealed in embryonic stem cells (ESCs) and in induced pluripotent stem cells (iPSCs) [5,6]. The stability and longevity of RNA molecules provide a great opportunity for non-invasive diagnosis and tumoral assessment [7]. We present multiple strategies for modulating proteostasis capacity, which may aid the urgently-needed therapies for age-dependent pathologies [5, 7-9].

The accurate relationship between lncRNAs and proteostasis can be explained, both phenotypically and molecularly, by the lncRNAs - binding proteins (RBP) interactions. These interactions are essential in performing all cellular functions and in preserving homeostasis.

RBPs, RNA binding proteins, have crucial roles in a myriad of cellular processes. The first step in analyzing their possible role includes identifying their binding partner. Also, lncRNAs' homeostasis (lncRNAstasis) paralleled the protein disruption in cellular senescence thus maintaining the correct cellular quality control (QC). Proteostasis mechanisms support the stabilization of accurately folded proteins, the heat shock protein family, and the mechanisms for lysosome and proteasome mediated protein breakdown $[10,11]$.

Nuclear lncRNAs modulate transcription by recruiting transcription factors to specific regions of nuclear DNA and also for ribonucleoprotein complexes with RBP. They participate in chromatin organization, gene expression, as well as structural scaffolds of nuclear domains. These complexes control gene expression at distinct key points, illustrating the critical role of lncRNA interaction with certain proteins in order to maintain cellular hemostasis [11].

The lncRNA pRNA interacts with DNA at the specific interaction point DNMT3B to control rRNA transcription [12]. In addition, PTENP1-asRNA alpha blocks transcription of PTEN coding gene by to DNMT3A (DNA methylase) at PTEN coding gene promoter [13]. PTENP1asRNA beta positively provides post transcriptional regulation of PTENP1 mRNA [11].

The nuclear enriched transcript 1 (NEAT) recruits paraspeckles RNA-binding proteins such as PSPC1, NONO/P54NR and PSF/SFPQ, directly or in a complex manner, and also suppresses gene expression by interaction with PRC1, PRC2, JARID1B, ESET and SUV39H1, chromatin binding protein/complexes [14, 15].

The IncRNA TERC, a telomerase RNA component, maintains telomere length, while the IncRNA THRILhnRNPL interactions modulate (TNF) $\alpha$ expression [16].

Cytoplasmic lncRNAs have different functions. They can act as translation regulators via base pairing with their target mRNAs or they can influence protein expression levels by increasing and decreasing mRNA stability [17, 18]. Another function of cytoplasmic lncRNAs is modulating ubiquitination process or controlling the passage of proteins or other RNAs between the cytoplasm and the nucleus [11]. Some lncRNAs indirectly regulate protein levels by influencing the available pool of miRNAs and, thereby, affecting mRNA turnover and translation. On the other hand, some lncRNAs interact directly with mRNAs, in order to enhance or suppress their translations, or with proteins, modulating their halflife time. For instance, the IncRNA GAS5 limits the "flow" of glucocorticoid receptor (GR) from the cytosol to the nucleus inhibiting GR mediated gene expression. In addition, the maternally expressed gene 3 (MEG3) which induces the p53 translation decreases the MDM2 expression while HuR can displace the lncRNA 7SL protein and also increases the p53 expression [19, 20]. Conversely, the highly expressed lncRNA 7SL could abolish p53 translation [11].

\section{Classification IncRNAs according to their mechanism of action}

LncRNAs are heterogeneous transcripts that are not translated into proteins or encoding for small proteins [9, 21]. They can be intergenic transcripts or large intergenic non-coding RNAs (lincRNAs), enhancer RNAs (eRNAs), or sense or antisense RNAs from the same or the opposite strand of mRNA that overlaps other genes. LncRNAs produced by RNA splicing have been revealed, such as circular RNAs (circRNAs), to derive from vestigial genes without coding potential, named pseudogene-encoded lncRNAs, from mRNA promoter regions, described as promoter-associated lncRNAs, as well as from introns, long intronic ncRNAs [22-24]. Competing endogenous RNAs (abbreviated ceRNAs), which manage RNA transcripts by competing for shared miRNAs, and circRNAs are stable and accumulate in great numbers [2, 25].

Remarkably, these IncRNAs have crucial roles in gene regulation, affecting different aspects of cellular homeostasis such as proliferation, migration or genomic stability by assembling transcriptional modulators, by base-pairing with mRNAs, by enrolling chromatin 
modification factors, as well as by interfering with RNAbinding proteins and leading to age-associated phenotypes relevant to multiple disease pathophysiologies associated with the aging process [2, 24, 26, 27].

Experimental evaluation of lncRNAs has clarified the importance of these biomolecules, that are not only a "transcriptional noise", but they perform a function elsewhere in the cell after they leave the transcription site. The non-coding transcriptome could reveal unexpected molecular activities, offering a great potential to distinguish between normal and disease states [24].

Table 1. $\operatorname{lncRNAs}$ in proteostasis.

\begin{tabular}{|c|c|c|c|c|c|}
\hline IncRNA & ARDs & $\begin{array}{l}\text { Function in } \\
\text { proteostasis }\end{array}$ & Target gene & $\begin{array}{l}\text { The cellular and molecular } \\
\text { effects of the IncRNA }\end{array}$ & Ref. \\
\hline $\begin{array}{l}\text { LncRNA- } \\
\text { MALAT1 }\end{array}$ & $\begin{array}{l}\text {-highly expressed in } \\
\text { cancer; Diabetic } \\
\text { nephropathy; } \\
\text {-atherosclerosis; } \\
\text { - neurodegenerative } \\
\text { processes }\end{array}$ & $\begin{array}{l}\text { Protein turnover } \\
\text { Scaffolding } \\
\text { Autophagy }\end{array}$ & $\begin{array}{l}\text {-HMGB1; } \beta \text { - } \\
\text { catenin; } \\
\text { - B-MYB; } \\
\text { - PDGF-BB } \\
\text { - ATG7 } \\
\text { (miR142-3p) }\end{array}$ & $\begin{array}{l}\text {-Inhibition of Tumor Cell Apoptosis; } \\
\text { - kidney fibrosis; restored podocytes } \\
\text { function; } \\
\text { - Phenotypic switching of VSMCs }\end{array}$ & $\begin{array}{l}{[34]} \\
{[77]} \\
{[81],[82]}\end{array}$ \\
\hline LincRNA-p 21 & $\begin{array}{l}\text {-skin cancer } \\
\text {-colorectal cancer } \\
\text {-prostate cancer }\end{array}$ & Protein turnover & $\begin{array}{l}\text { p53; } \\
\text { HIF-1 } \alpha \\
\beta \text {-catenin } \\
\text { Jun B mRNA }\end{array}$ & $\begin{array}{l}\text { cell cycle arrest; apoptosis in } \\
\text { keratinocytes; represses translation of } \\
\text { cancer proteins }\end{array}$ & $\begin{array}{l}{[7],[37],} \\
{[54]} \\
{[83],[84]}\end{array}$ \\
\hline $\begin{array}{l}\text { LncRNA } \\
\text { CND1/cyclin } \\
\text { D1 }\end{array}$ & $\begin{array}{l}\text { - many cancer types; } \\
\text { - BCL2; } \\
\text {-breast cancer }\end{array}$ & -Protein turnover & $\begin{array}{l}\text { - TLS } \\
\text {-cyclin D1 }\end{array}$ & $\begin{array}{l}\text { - cell cycle regulator in cancer } \\
\text {-benefits in breast cancer therapy }\end{array}$ & {$[38],[39]$} \\
\hline $\begin{array}{l}\text { LncRNA- } \\
\text { HOTAIR }\end{array}$ & $\begin{array}{l}\text {-breast, gastric, and } \\
\text { colorectal tumors; } \\
\text { - nasopharyngeal } \\
\text { cancer }\end{array}$ & $\begin{array}{l}\text {-Protein turnover; } \\
\text { - Scaffold function }\end{array}$ & $\begin{array}{l}\text {-PRC2 } \\
\text { - Snurportin-1; } \\
\text { Ataxin-1 }\end{array}$ & $\begin{array}{l}\text { - cell proliferation, invasion, } \\
\text { aggression, and metastasis; } \\
\text { inhibition of apoptosis } \\
\text { - prevents cellular senescence }\end{array}$ & $\begin{array}{l}{[31]} \\
{[29]} \\
{[42],[45]}\end{array}$ \\
\hline Lnc AS Uchl1 & $\begin{array}{l}\text {-neurodegenerative } \\
\text { diseases; } \\
\text {-cancer; } \\
\text {-auditory cortex } \\
\text { senescence }\end{array}$ & Protein turnover & $\begin{array}{l}\text {-MDM2; } \\
\text {-UPS-related } \\
\text { proteins: p53, } \\
\text { p14; ARF, } \\
\text { p27KIPI, } \\
\text { ubiquitinated } \\
\text { proteins, } \\
\text { monoubiquitin, } \\
\text { BE1, PSMA7 }\end{array}$ & $\begin{array}{l}\text { - intensifies translation of } \\
\text { UCHL1, which plays an important } \\
\text { role in the UPS system }\end{array}$ & $\begin{array}{l}{[49]} \\
{[50]} \\
{[51]}\end{array}$ \\
\hline LncRNA & & -Protein turnover; & YBX1; & -Inhibits cellular proliferation & {$[52],[85]$} \\
\hline GAS5 & $\begin{array}{l}\text {-gastric carcinoma } \\
\text {-prostate cancer }\end{array}$ & $\begin{array}{l}\text {-Membrane } \\
\text { trafficking }\end{array}$ & $\begin{array}{l}\text { E2F1; } \\
\text { P27Kip1 }\end{array}$ & - a growth arrest lncRNA & \\
\hline $\begin{array}{l}\text { Lnc RNA } \\
\text { PANDA }\end{array}$ & -senescence. & $\begin{array}{l}\text { Membrane } \\
\text { trafficking }\end{array}$ & $F A S ; B I K ; p 53$ & $\begin{array}{l}\text { inhibits DNA-damage-induced } \\
\text { apoptosis }\end{array}$ & {$[86]$} \\
\hline $\begin{array}{l}\text { Lnc } \\
\text { ANRASSF1 }\end{array}$ & $\begin{array}{l}\text {-breast, osteosarcoma, } \\
\text { colorectal, liver, } \\
\text { bladder, renal } \\
\text { cell carcinoma }\end{array}$ & $\begin{array}{l}\text {-Membrane } \\
\text { trafficking; } \\
\text {-Scaffold function }\end{array}$ & $\mathrm{PRC} 2$ & $\begin{array}{l}\text { Control of proliferation, metabolism, } \\
\text { apoptosis and senescence; histone } \\
\text { modifications }\end{array}$ & {$[36],[87]$} \\
\hline $\begin{array}{l}\text { LncRNA } \\
\text { Gadd } 7\end{array}$ & $\begin{array}{l}\text { - is expressed in } \\
\text { response to oxidative } \\
\text { stress }\end{array}$ & $\begin{array}{l}\text { Membrane } \\
\text { trafficking }\end{array}$ & $\begin{array}{l}\text { TDP- } 43 \text {, } \\
\text { modulates Cdk6 } \\
\text { levels }\end{array}$ & controlling cell-cycle progression & [88] \\
\hline $\begin{array}{l}\text { LncRNA } \\
7 \mathrm{SL}\end{array}$ & $\begin{array}{l}\text {-widely upregulated } \\
\text { in cancer tissues }\end{array}$ & $\begin{array}{l}\text {-Autophagy } \\
\text {-Protein trafficking }\end{array}$ & $\begin{array}{l}\text { p53; } \\
\text { HuR }\end{array}$ & cellular senescence & {$[70],[36]$} \\
\hline $\begin{array}{l}\text { Lnc RNA } \\
\text { DICER1 }\end{array}$ & $\begin{array}{l}\text {-ovarian cancer; } \\
\text { - tongue squamous cell } \\
\text { carcinoma }\end{array}$ & Autophagy & miR-675 & $\begin{array}{l}\text {-A key synthesis-related factor of } \\
\text { miRNA related to tumor cell } \\
\text { activities; } \\
\text { - cellular proliferative and invasive } \\
\text { capacities }\end{array}$ & [89] \\
\hline $\begin{array}{l}\text { LncRNA } \\
\text { HULC }\end{array}$ & $\begin{array}{l}\text { - tumor } \\
\text { chemoresistance; } \\
\text {-hepatocellular } \\
\text { carcinoma }\end{array}$ & Autophagy & $\begin{array}{l}\text {-COX-2 } \\
\text { USP22/COX-2" } \\
\text { axis; } \\
\text { - Sirt1 }\end{array}$ & $\begin{array}{l}\text { Increase triglyceride and cholesterol } \\
\text { levels in hepatoma cell }\end{array}$ & [64] \\
\hline Lnc MEG3 & $\begin{array}{l}\text {-colorectal cancer } \\
\text { - Huntington's disease }\end{array}$ & $\begin{array}{l}\text { Autophagy } \\
\text { Growth arrest }\end{array}$ & $\begin{array}{l}\text { MDM2; } \\
\text { p53 }\end{array}$ & -blocks apoptosis & {$[20]$} \\
\hline
\end{tabular}




\begin{tabular}{|c|c|c|c|c|c|}
\hline LincRNA $H 19$ & $\begin{array}{l}\text {-breast cancer; } \\
\text {-human tumor growth; } \\
\text { - Gastric } \\
\text { Carcinogenesis }\end{array}$ & Scaffold function & $\begin{array}{l}\text {-E2F1, PRC2, } \\
\text { HuR, KSRP }\end{array}$ & $\begin{array}{l}\text {-suppression of RBmRNA via } \\
\text { miR675; } \\
\text {-DNA methylation; cell division } \\
\text { cycle }\end{array}$ & $\begin{array}{l}{[102],} \\
{[103],} \\
{[104]}\end{array}$ \\
\hline $\begin{array}{l}\text { LncRNA } \\
\text { PRNCR1 }\end{array}$ & $\begin{array}{l}\text {-prostate cancer } \\
\text {-CRC }\end{array}$ & Scaffold function & - AR & $\begin{array}{l}\text { - regulation of AR-dependent gene } \\
\text { activation events- }\end{array}$ & {$[74],[90]$} \\
\hline $\begin{array}{l}\text { LncRNA } \\
\text { PCGEM1 }\end{array}$ & -prostate cancer & Scaffold function & $-\mathrm{AR}$ & -tumor type-specific super-enhancer & {$[74],[90]$} \\
\hline LncTERC & $\begin{array}{l}\text {-premature neural } \\
\text { aging in terc } \mathrm{KO} \text { mice }\end{array}$ & Scaffold function & TRF1, TRF2 & $\begin{array}{l}\text { - Promotion of telomere extension } \\
\text {-controlling the survival of NSCs } \\
\text { - prevention of premature senescence } \\
\text { and aging }\end{array}$ & $\begin{array}{l}{[2],[30],} \\
{[91]}\end{array}$ \\
\hline Lnc TERRA & -neural aging & Scaffold function & TRF1, TRF2 & $\begin{array}{l}\text {-Suppression of telomere extension } \\
\text {-survival of NSCs }\end{array}$ & {$[2],[30]$} \\
\hline Lnc ANRIL & $\begin{array}{l}\text {-upregulated in } \\
\text { prostate cancer; } \\
\text { - myocardial infarction } \\
\text { - hyper- } \\
\text { cholesterolemia } \\
\end{array}$ & $\begin{array}{l}\text {-Protein turnover; } \\
\text {-Scaffold function }\end{array}$ & $\begin{array}{l}\text {-CBX7 } \\
\text { - let-7a/TGF- } \\
\beta 1 / \text { Smad } \\
\text { signaling } \\
\text { pathway }\end{array}$ & $\begin{array}{l}\text {-proliferation and migration of } \\
\text { prostate cancer cells } \\
\text { - antisenescence function } \\
\text {-histone modification }\end{array}$ & {$[41]$} \\
\hline $\begin{array}{l}\text { OX-2-Cyclooxy } \\
\text { amage-inducibl } \\
\text { otein } 1 ; \text { MALA } \\
\text { gulatory proteir } \\
\text { atelet-derived g } \\
\text { oteasome subur } \\
\text { elomeric repeat }\end{array}$ & $\begin{array}{l}\text { Metastas is Associated } \\
\text { EG3- maternally expre } \\
\text { h factor- BB; PRC2-; PI }\end{array}$ & $\begin{array}{l}\text { pecific transcript } \\
\text { gene } 3 \text {; B-MYB } \\
\text { R1-prostate canc } \\
\text { na protein; Sirt1- }\end{array}$ & $\begin{array}{l}\text { actor that int } \\
-1 \alpha-\text { Hypoxi } \\
\text { script } 1 ; \text { MDI } \\
\text { oblastosis Vir } \\
\text { coding RNA } 1\end{array}$ & $\begin{array}{l}\text { LL/lymphom } \\
\text { liretly with RB; FAS -; Gadd7- grow } \\
\text { cible factor } 1 \text {-alpha; HMGB1-High-m } \\
\text { ouse double minute } 2 \text { protein; KSRP- } \\
\text { ogene; NSCs- neural stem cells; PAND } \\
\text { EM1- prostate cancer gene expression m }\end{array}$ & $\begin{array}{l}\text { x } 7 \text { protein; } \\
\text { rrested DNA } \\
\text { ty group box } \\
\text { type splicing } \\
\text {; PDGF-BB- } \\
\text { 1; PSMA7 } \\
\text { nent; TERRA } \\
\text { cular smooth }\end{array}$ \\
\hline
\end{tabular}

\section{LncRNAs in proteostasis}

Aging is associated with the progressive deterioration of proteostasis, a portmanteau of two words, protein and homeostasis. It encompasses competing and integrated processes that control protein biogenesis, folding, interactions, trafficking and degradation within and outside the cell. Proteostasis dysfunction, including autophagy and the ubiquitin-proteasome pathways, leads to age-related diseases (ARDs) such as Alzheimer's disease, cancer and other degenerative disorders, being an accepted aging factor $[2,28,29]$. In line with this, we summarize proteostasis-related lncRNAs associated with protein turnover (synthesis and degradation), trafficking and autophagy (Table 1).

\section{LncRNAs associated with protein turnover}

Protein turnover represents the balance between protein synthesis and protein degradation. This process decreases with age in all senescent organisms. Protein turnover occurs in the brain and may contribute to protein aggregation and neurodegeneration, disturbing physiological neurogenesis and synaptic plasticity [2, 30].

Protein degradation is driven by the ubiquitin proteasome pathway. Protein synthesis depends on mRNA level. The translation rate is modulated by lncRNAs indirectly by affecting the pool of miRNAs, suppressing the mRNA turnover and translation
(lincRNA-ROR and linc-MD1), or through direct interaction with proteins and mRNAs, modifying their translation [2].

Perturbations of protein-RNA interactions are involved in metabolic and autoimmune diseases, cancer, neurological and muscular disorders. Many RNA-binding proteins (RBP) such as heterochromatin protein 1, malespecific lethal-1 (MSL), the catalytic subunit of MSL histone acetyltransferase (HAT) enzyme complex (MOF), deafness dystonia peptide 1 (DDP1), Trithorax-group and Polycomb-group implicated in distinct tumor stages bind lncRNAs [31].

LncRNA-MALAT. LncRNA metastasis-associated lung adenocarcinoma transcript 1 (MALAT1), a cell cycle regulator whose depletion triggers $\mathrm{G} 1$ or G1/S arrest by suppressing cell proliferation and growth activating senescence phenotype [32] and a high expression molecular predictor of poor survival rates in cancer, interacts with splicing regulatory (SR) protein family members. This lncRNA triggers two cell-cycle regulators, cyclins A2 and B1, and controls the oncogenic transcription of myeloblastosis viral oncogene B (BMYB) $[33,34]$.

LincRNA-p21 regulates $p 21$ by recruiting hnRNPK and reducing cell proliferation. It also affects somatic cell reprogramming via cell senescence or apoptosis pathway [32]. This lincRNA, interacting with cadherin-associated protein, beta (CTNNB) mRNAs, encoding $\beta$ catenin via the Wnt/ßcatenin signaling pathway and decreasing oxidant stress, could have antisenescent effects in 
doxorubicin (Dox)treated HL1 murine cardiomyocytes, where it was shown to have a high expression [35]. LincRNA-p21 is also induced by hypoxia-inducible factor $1 \alpha$ (HIF-1 $\alpha$ ), being able to bind this factor, and by UVB via the p53 pathway, having an important role in UVBinduced apoptosis. Urinary levels of LincRNA-p21 IncRNA may help discriminating between prostate cancer and benign prostatic hyperplasia [7, 36, 37].

LncRNA CND1/cyclin D1, a cell cycle regulator in many cancers, is transcribed from the cyclin D1 gene promoter region. It interacts with the translocated liposarcoma (TLS) protein, a sensor for the detection of DNA damage [38]. High levels of cyclin D1 expression are associated with better outcomes of adjuvant trastuzumab therapy in HER2-positive early breast cancer [39].

LncRNA ANRIL. This IncRNA, transcribed from the inhibitor of kinase 4 (INK4) locus, is the antisense noncoding RNA in INK4 (ANRIL). It interacts with both CBX7, a component of the polycomb group protein regulator of cytokinesis (PRC1), where it activates epigenetic silencing of the CDKN2A/CDKN2B loci, and SUZ12, a component of PRC2. Its down-regulation induces translation of the cell cycle inhibitors such as P14, P15 and P16. Additionally, the lncRNA MIR31HG interacts with both PRC1 and PRC2 complexes to suppress the P16INK4A expression [Ghanam]. LncRNA ANRIL is upregulated in prostate cancer, interacting with the chromobox 7 (CBX7) protein, part of the polycomb group protein regulator of cytokinesis (PRC1) protein complex [31, 40]. This lncRNA activates the proliferation and migration of prostate cancer cells through the let$7 \mathrm{a} / \mathrm{TGF}-\beta 1 /$ Smad signaling axis [41].

LncRNA HOTAIR, up-regulated during the aging process, increases ubiquitination degradation of Snurportin-1 (SNUPN) and Ataxin-1 (ATXN1) by functioning as a scaffold for DAZ interacting zinc finger protein (DZIP3) and Mex-3 RNA binding family member $\mathrm{B}$ (MEX3B) and their corresponding substrates [11].

HOTAIR is one of the first lncRNAs linked to cancer. It interacts with polycomb repressive complex 2 (PRC2), a histone methyltransferase and lysine-specific histone demethylase 1A (LSD1), an illustration of histone demethylase [31, 42, 43]. During aging, this lncRNA is degraded by the senescence repressor HuR, a miRNA200a dependent RBP, due to its binding to the $3^{\prime}$ UTR of $c$ Jun mRNA in a region including this miR binding site [44]. HOTAIR prevents cellular senescence through the decay of Snurportin-1 and Ataxin-1 targets via the ubiquitination pathway. Ectopic expression of lncRNA HOTAIR determines inflammation through NF- $\mathrm{BB}$ activation and through interleukin (IL)-6 expression [45, 46, 47]. MiRNA-203 inhibits HOTAIR, regulating tumorigenesis via the epithelial-to-mesenchymal transition (EMT) pathway [48] (Fig. 1).

Lnc AS Uchl1 (ubiquitin C-terminal hydrolase L1) intensifies translation of UCHL1, which plays an important role in the ubiquitin proteasome system (UPS) and in many other cellular processes such as differentiation, cell proliferation, as well as in brain function and in neurodegenerative diseases. Loss of function of UCHL1 leads to serious degenerative modifications in the central nervous system, this proteolytic deficit contributing to neurological conditions $[49,50]$. Overexpression of UCHL1 decreased mouse double minute 2 (MDM2) levels, a factor involved in cancers, and increased the UPS-related proteins such as p53, p14, ADP-ribosylation factor (ARF), p27KIPI, ubiquitinated proteins, monoubiquitin, $\mathrm{BE} 1$, proteasome subunit alpha type 7 (PSMA7) and the proteasomal activity, the last five systems being implicated in auditory cortex senescence $[49,51]$.

LncRNA GAS5. Growth arrest specific transcript 5 (GAS5) was shown to interact with Y-box binding protein 1 (YBX1) through the GAS5/YBX1/p21 pathway, and the knockdown of lncRNA GAS5 was demonstrated to accelerate YBX1 protein turnover without affecting its gene expression. LncRNA GAS5 downregulation lowers YBX1 protein concentration, interfering with YBX1transactivated p21 transcription and abrogating G1 phase cell cycle arrest in gastric carcinoma. The lncRNA GAS5/YBX1/p21 axis was proved to be a useful target for developing lncRNA-based treatment for cancer [52].

\section{LncRNAs in protein membrane trafficking}

Membrane trafficking is the cornerstone of molecular biology. It compartmentalizes cells into functional recognizable units for signal initiation and processing. It is generally accepted that deregulated membrane trafficking leads to pathological aging. Kes1/Osh4, a member of the oxysterol binding protein-related protein (ORP) superfamily, and other ORPs, activate cell-cycle control functions, inhibiting phosphatidylinositol transfer protein (Sec14)-dependent membrane trafficking using the trans-Golgi (TGN)/endosomal network, inhibiting the $\mathrm{G}_{1} / \mathrm{S}$ transition, when cells are under caloric restriction (CR). Therefore, replicative aging is encouraged. Kes1dependent cell-cycle control depends on the Greatwall/MASTL kinase ortholog Rim15 and is in opposition to the Sec14 action in a mechanism independent of Kes1/Sec14 total membrane-trafficking actions. ORPs define a family of stage-specific cell-cycle regulation factors with tumor suppressor-like functions [53]. 


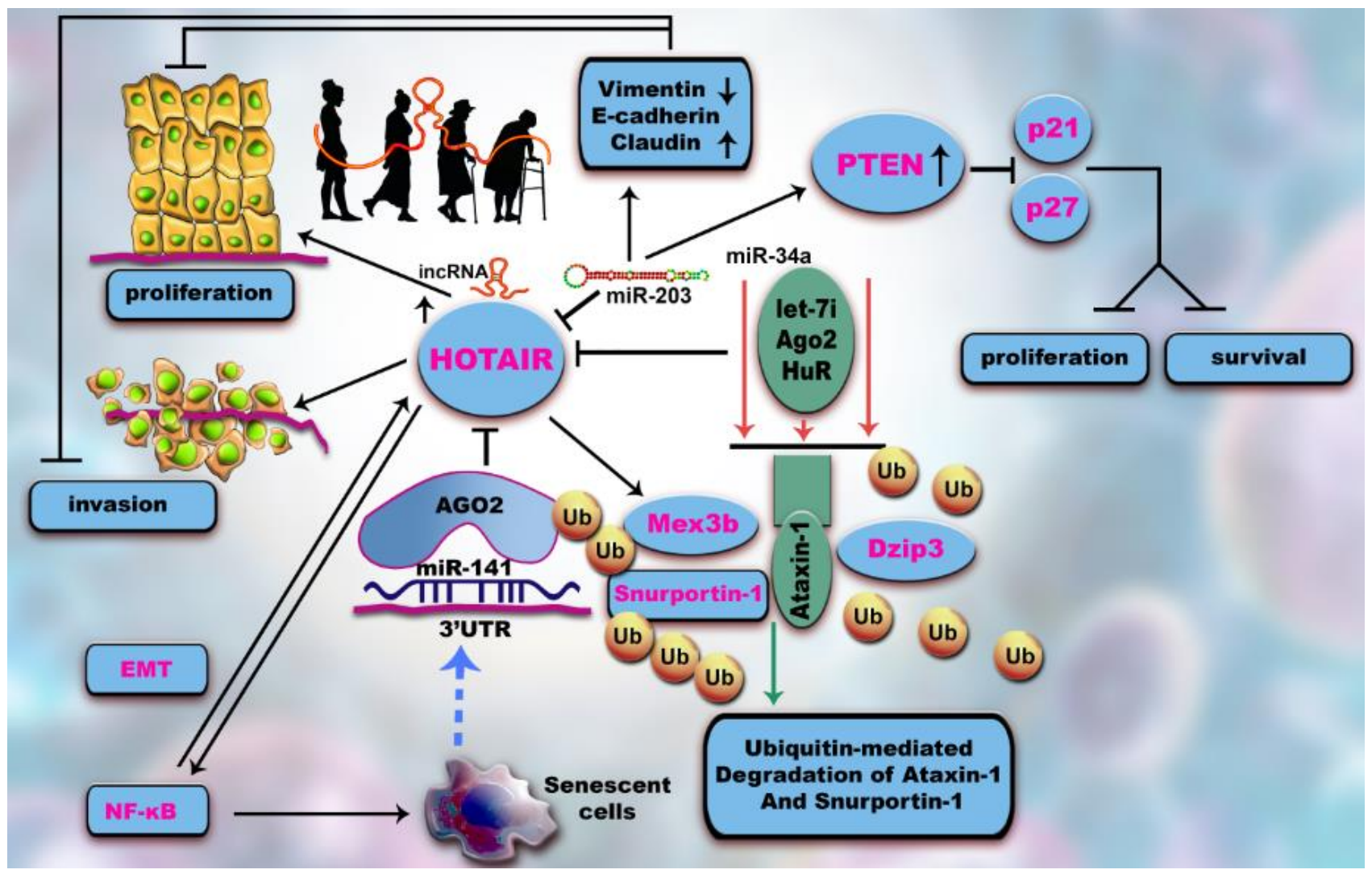

Figure 1. Altered HOTAIR regulation contributes to ARDs/ senescence. HOTAIR, overexpressed during aging, activates proliferation and invasion. miR-141 levels are inversely correlated with malignacy by binding to this lncRNA and thus abrogating its transcription. Both interact with/are linked to Argonaute 2 (Ago 2) complex. A positive feedback mechanism from senescent cells upregulates miR-141. The level of HOTAIR could be reduced in a micro-dependent manner by an RNA binding protein (RBP), the senescence-repressor HuR, which degrades this lncRNA. In addition, HOTAIR facilitates ubiquitination and proteolysis of Snurportin1 and Ataxin-1. HOTAIR interacts with E3 ubiquitin ligases and with their ubiquitination substrates, Ataxin-1 and Snurportin-1. HOTAIR facilitates the ubiquitination of Ataxin-1 by Dzip3 and Snurportin-1 by Mex3b and accelerates their degradation. HOTAIR has a key role in cellular senescence through inducing extended expression of NF- $\kappa$ B target genes and also NF- $\kappa$ B activation during DNA damage. An NF-kB-HOTAIR axis leads to a positive-feedback loop cascade contributing to cellular senescence and chemotherapy resistance in cancers. Overexpression of miR-203 inhibits HOTAIR, triggering epithelial- mesenchymal-transition (EMT), therefore inducing cell-cycle arrest and apoptosis. The expression of phosphatase and tensin homolog (PTEN), E-cadherin and claudin is increased by blocking invasion and metastasis while p21 and p27 are downregulated.

Cell cycle is strictly regulated by cyclin-dependent kinases (CDKs) and several related pathways such as p53 and the retinoblastoma protein $(\mathrm{pRB})$. Current research on lncRNAs outlines their involvement in the control of key cell cycle regulators such as p53, pRB, cyclins, CDKs, and CDK inhibitors. These lncRNAs are epigenetic regulators and transcription and post-transcription regulators for primary control cellular levels of cell cycle modulators through different mechanisms. Sometimes, certain IncRNAs are induced by DNA damage, leading to cell cycle arrest or apoptosis as a response to DNA damage. Consequently, deregulations of lncRNAs are involved in tumoral genesis and in chronic inflammation and they could represent possible molecular targets for both cancer diagnosis and therapy [54].
LncRNA-P21-associated ncRNA DNA damageactivated (PANDA) is specifically induced by DNA damage through the p53 pathway, through binding the nuclear transcription factor $\mathrm{Y}$ subunit $\alpha$ (NF-YA). Its activation is prevented and the expression of proapoptotic genes is suppressed. The interaction between NF-YA and p53 disrupts the cell cycle and senescence $[8,53]$.

Lnc RNA GAS5 is a growth arrest lncRNA involved in human malignancies. It inhibits the transcription of glucocorticoid receptor (GR) by blocking this nuclear receptor in the cytoplasm $[52,55]$. Later on, it was shown to have a role on mESC proliferation. LncRNA Gas5 has a key role in controlling iPSC reprogramming, selfrenewal and pluripotency of mESCs. The knockdown of Gas5 facilitates endodermal differentiation of mESCs and reduces the efficiency of iPSC reprogramming through 
the Dicer-miR291a-cMyc axis. It is also involved in the DNA demethylation course in mESCs [5].

ANRASSF1. This lncRNA forms an RNA/DNA hybrid at the transcriptional start site of RASSF1A, a gene encoding the Ras association domain-containing protein 1. It becomes hypermetilated during aging. Ras proteins, members of a superfamily of GTP-ases, have a key position in numerous signaling networks, counting the IIS action, controling proliferation, metabolism, apoptosis and senescence. The hyperactivation of Ras or mutant Ras proteins is difficult to target (the intrinsic enzyme activity becomes defective and it freezes them in a highly active oncogenic GTP-bound state) [36].

Gadd7. It supervises cell growth and the G1/S checkpoint induced by oxidative stress and DNA damage, destabilizing CDK6 mRNA through direct association with TAR DNA-binding protein 43 (TDP-43). This leads to cell senescence and it could be a possible biomarker for frontotemporal lobar degeneration (FTLD) [52, 56, 57].

7SL. This widely expressed lncRNA in cancer cells is involved in cell proliferation and is an integral component of "signal recognition protein" (SRP) [58]. 7SL interacts with RBP HuR, promoting translation of p53, the most important growth regulator and tumor suppressor protein [59].

\section{LncRNAs in autophagy}

Autophagy is a versatile and protective degradation process supervising cellular quality control during the aging process [60]. The autophagic flux depends on direct improvement in somatic conservation and proteostasis. Therefore, the intracellular proteostatic signalling pathways are involved in transfering autophagic status between cells and tissues, controlling ARDs on a systemic level [61]. Certain IncRNAs were recently found to control autophagy.

H19, a suppresed lncRNA in patients with high blood sugar and diabetic cardiomiopathy, abolishes autophagy by repressing a GTPase DIRAS3, a tumor suppresing gene, therefore regulating ATG7 gene expression [61, 62].

LncRNA DICER1 - antisense RNA 1 (AS1) has an important role in autophagy and tumoral progression. Overexpressed in osteosarcoma cells, this lncRNA knockdown could suppress autophagy by inhibiting the expression levels of certain proteins as follows: autophagy-5 (ATG5), microtubule-associated protein light chain 3 (LC3-II) involved in autophagosome membrane expansion, and beclin 1, an apoptotic promoter. Moreover, miR-30b targets 3'-UTR of DICER1-AS1 and ATG5 [63].

LncRNA HULC. Considerable research has revealed that autophagy is a key factor in tumoral chemoresistance and that lncRNA HULC is highly induced in liver cancer by therapy with antitumoral reagents such as oxaliplatin, 5-fluorouracil and pirarubicin (THP), which leads to protective autophagy. In human HCC tissues, the mechanism is mediated by the silent information regulator 1 (Sirt1) protein, the level of HULC being positively correlated with that of Sirt1. The pathway 'HULC/ubiquitin-specific peptidase 22 (USP22)/Sirt1/protective autophagy' increases HCC cells sensitivity to chemotherapeutic agents. This pathway could be a novel target for sensitizing HCC cells to HCC chemotherapy [64]. Mechanistically it was found that HULC could act as a molecular sponge of miR-372, 107 and 186 thus promoting tumorigenesis [65] (Fig. 2). This IncRNA increases expression of becline-1, an autophagy related gene, and also the interplay between LC3 and ATG3 during hepatocarcinogenesis [66].

LncRNA MEG3. The lncRNA MEG3 gene was shown to be involved in colorectal cancer, controlling certain cellular and molecular processes such as autophagy and growth arrest by suppressing MDM2, upregulating p53 and blocking apoptosis $[20,67,68]$. This lncRNA could be a novel biomarker for predicting clinical outcome in cancer [69].

LncRNA 7SL. 7SL-depleted cells are lead to cellular senescence and autophagy due to the competitive binding between HuR and 7SL, which can be removed, increasing the p53 gene expression. It also blocks the cell cycle and enhances senescence and autophagy [70].

Other examples of IncRNAs involved in controlling all autophagic stages are HOTAIR, MALAT1, NBR2, PTENP1, and recently NEAT1 activating autophagy in Parkinson's disease via PINK1 protein [71, 61]. Equivalently, IncRNAs GAS5 and CAIF modulate ATG3 in certain pathological conditions such as osteosarcoma, myocardial infarction and cancer [72, 61].

\section{LncRNAs: scaffold function}

LncRNAs could serve as protein scaffolds, participating in the assembly of ribonucleoproteins that link the factors together to produce new functions. The association between lncRNAs and disease may involve their scaffolding capacity. Certain lncRNAs present specific protein-binding domains that incorporate each molecule together. This action may have an impact on transcription or repression processes [73, 74]. 


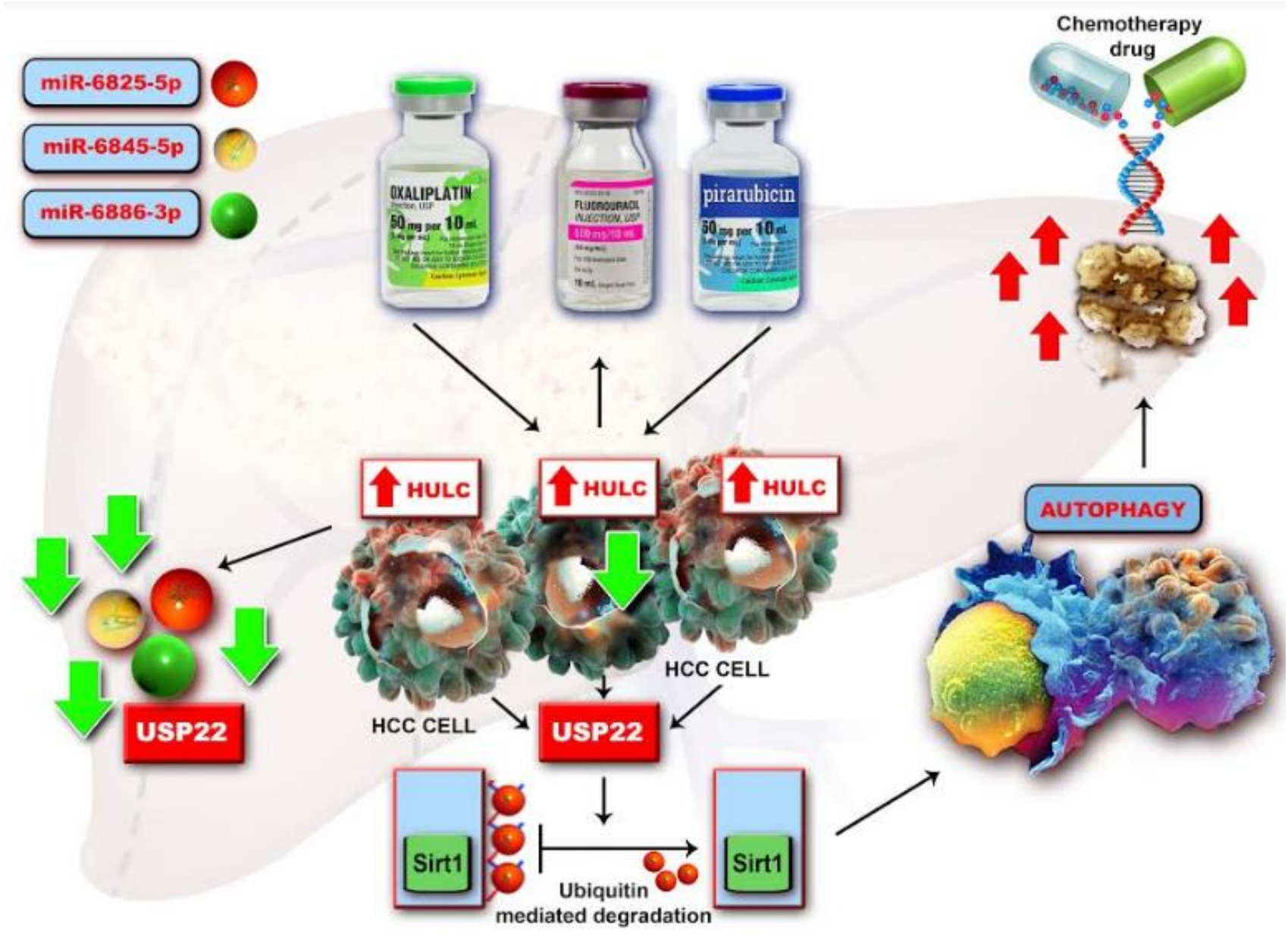

Figure 2. Mechanism by which IncRNA HULC activates tumorigenesis. Abbreviations: CLOCK- circadian locomotor output cycles kaput; E2F1-transcription factor involved in cell cycle regulation and apoptosis; HCC- hepatocellular carcinoma; HIF-1 $\alpha$-_hypoxia-inducible factor 1-alpha; HMGA2- high mobility group A protein 2; HULC- highly upregulated in liver cancer; PRKACB- protein kinase cAMP-activated catalytic subunit beta; PTTG1- pituitary tumor transforming gene; siRNA- small interfering ribonucleic acid; TWIST- the basic helix-loop-helix transcription factor; YAP- yes-associated protein 1. IncRNA HULC, highly expressed in liver cancer, modulates the oncogene HMGA2 to activate tumorigenesis and interacts with the CLOCKmRNA, leading to the enhancement of its transcription. HMGA2 plays an essential role in the genesis of lung cancer, gastric cancer and colorectalcarcinoma. HULC could be considered a molecular sponge which sequester certain miRNAs such as miR-186, miR-107 as well as miR-372, therefore reducing the translational repression of HMGA2, E2F1 and PRKACB. The expression level of HULC is positively correlated with HMGA2 and opposite to miR-186. In human HCC tissues, HULC upregulated HMGA2 expression via sequestering miR186 promotes tumorigenesis. Moreover, HULC induces the expression of cyclin A and IL-15 in a dose-dependent manner. In HCC, HMGA2 is inhibited by miR-107 and let-7 miR-107 in breast cancer as well as siRNA as a consequence of HULC inhibition.

LincRNA H19 controls a collection of genes consisting of H19 and insulin-like growth factor-2 (IGF2) through the interaction with methyl-CpG-binding domain protein 1 (MBD1). Therefore, a ribonucleoprotein complex H19-MBD1 is formed. It represses gene expression by recruitment of histone lysine methyltransferases. Both H19 and IGF2 are involved in aging. Moreover, their increased level promotes ARDs [75].
LncRNAs PRNCR1 and PCGEM1. Two lncRNAs, namely prostate cancer non-coding RNA 1 (PRNCR1) and prostate cancer gene expression marker 1 (PCGEM1), generally overexpressed in the most aggressive forms of prostate cancers, precisely bind to the androgen receptor (AR) and strongly amplify androgen receptor-mediated gene expression in both ligand-independent and dependent pathways [75]. 
Table 2. Senescence- a ssociated lncRNAs and neurodegenerative disorders.

\begin{tabular}{|c|c|c|c|}
\hline IncRNA/expression & Implication in neurodegenerative disorders & $\begin{array}{l}\text { Abnormalities in } \\
\text { neuronal process/ } \\
\text { Clinical features } \\
\end{array}$ & Reference \\
\hline $\begin{array}{l}\text { MEG3 } \\
\text {-expressed in the } \\
\text { nucleus and } \\
\text { cytoplasm }\end{array}$ & $\begin{array}{l}\text {-upregulated in the hippocampus of old mice; } \\
\text {-downregulated in old induced } \\
\text { striatal medium-sized spiny neurons (MSSNs); } \\
\text { - PTEN/PI3K/AKT signaling cascade }\end{array}$ & $\begin{array}{l}\text {-cognitive decline } \\
\text {-downregulated in HD brain tissue } \\
\text { - synaptic plasticity in neurons }\end{array}$ & {$[30],[92]$} \\
\hline SORL1-AS & $\begin{array}{l}\text { - upregulated in } \mathrm{AD} \text { disease brain affecting } \mathrm{A} \beta \\
\text { formation }\end{array}$ & $\begin{array}{l}\text {-AD; } \\
\text {-Protein aggregation; } \\
\text {-cognitive impairment }\end{array}$ & [30], [93] \\
\hline $\begin{array}{l}\text { Six } 30 S \\
\text {-spatiotemporal } \\
\text { expression }\end{array}$ & $\begin{array}{l}\text { - Regulation of Six } 3 \text { targets through } \\
\text { interactions with Eya proteins and the } \\
\text { chromatin-modifying protein Ezh2; }\end{array}$ & - adult mouse neurogenesis & [94] \\
\hline $17 \mathrm{~A}$ & $\begin{array}{l}\text {-upregulated in frontal and temporal cortices } \\
\text {-increases } A \beta \text { secretion }\end{array}$ & $\begin{array}{l}\text {-AD; } \\
\text {-Abolish GABA B2 intracellular signaling }\end{array}$ & [95] \\
\hline MALAT-1 & $\begin{array}{l}\text { - upregulated in human aged SVZ; } \\
\text { - upregulated in the hippocampus of old mice; } \\
\text { - scaffold for proteins and RNAs }\end{array}$ & $\begin{array}{l}\text {-cognitive decline; } \\
\text {-neurodegeneration; } \\
\text {-PD }\end{array}$ & $\begin{array}{l}{[30],[96],} \\
{[97]}\end{array}$ \\
\hline UCHL1-AS & $\begin{array}{l}\text {-downregulated in murine dopaminergic cells; } \\
\text { - regulated by a transcription factor Nurr } 1 \\
\text { required for dopamine cells differentiation }\end{array}$ & $\begin{array}{l}\text { - Neurodegeneration; } \\
\text {-PD }\end{array}$ & {$[50]$} \\
\hline ANRIL & -altered expression in all tissues & $\begin{array}{l}\text {-AD; } \\
\text { - Neurodegeneration; }\end{array}$ & [98] \\
\hline HOTAIR & - high expression of HOTAIR promotes PD & $-\mathrm{PD}$ & [99] \\
\hline BACE1-AS & $\begin{array}{l}\text { - Increases BACE } 1 \text { mRNA stability } \\
\text { and } A \beta 42 \text { formation }\end{array}$ & - up-regulated in AD brains & $\begin{array}{l}{[100],} \\
{[101]}\end{array}$ \\
\hline
\end{tabular}

After the interaction between PRNCR1 and AR, the association of disruptor of telomeric silencing 1 like histone H3 methyltransferase (DOT1L) to the PRNCR1AR complex is accelerated through acetylation at the Cterminal of AR protein. DOT1L mediates $\mathrm{N}$-terminal acetylation of AR protein, which increases the enrollment of lncRNA PCGEM1. In prostate cancer cells, translation of short hairpin RNA targeting these two lncRNAs was shown to actively suppress proliferation of cancer cells and tumor growth in murine models [76].

LncRNA MALAT1. The downregulation of MALAT1 decreased platelet-derived growth factor-BB (PDGF-BB)-induced proliferation and migration by inhibiting autophagy. MALAT1 functions as a competing endogenous RNA (ceRNA) controlling autophagy-related 7 (ATG7) gene transcription via sponging miR142-3p. It switches the phenotype of vascular smooth muscle cells (VSMCs) with consecutive proliferation, contributing to different vascular conditions such as atherosclerosis, transplant vasculopathy, in-stent restenosis, or vein bypass graft failure [77].

\section{LincRNA HOTAIR}

LncRNAs - Telomerase RNA Component (TERC) and telomeric repeat containing RNA (TERRA) are telomerase limiting factors maintaining telomere length and controlling the survival of neural stem cells (NSCs) in neural aging $[2,30]$ (Table 2). LncRNA TERC provides a template for the biosynthesis of telomeric units and forms a complex with other proteins. In addition, this lnc has a catalytic function through adding telomere repeats [78]. Dysregulation of TERRA leads to premature aging; elevated levels in particular result in a specific syndrome consisting of immunodeficiency, facial dysmorphism and centromeric instability [79, 80] (Fig. 2).

\section{Conclusions}

Aging is governed by important adjustments in protein expression patterns modulated by lncRNAs, which critically modify both the pathological and physiological decline associated with senescence. Their potential usefulness in cancer or neurodegenerative diseases is not fully clarified at present. However, we can see the refined mechanisms involving the regulatory interaction between lncRNAs, miRNAs and RBPs as key actors which could 
represent novel targets for future therapeutic interventions.

In summary, this analysis on lncRNAs has revealed, through a deeper molecular undestanding, that they are truly age-related functional biomolecules with a vital contribution in normal physiology or aging-associated dysfunction.

\section{Conflict of Interest}

The authors declare that the research was conducted in the absence of any commercial or financial relationships that could be construed as a potential conflict of interest.

\section{Acknowledgements}

This work is was supported by ACHILE, FDI and ECHITAS projects: a project CNFIS-FDI (CNFIS-FDI2019-0666), entitled "Sustenance and valorification of research of excellence in the domain of personalized medicine by internationalization and increasement of research activities visibility", PDI-PFE-CDI 2018 ctr 29PFE/18.10.2018 entitled "Increasing the performance of scientific research and technology transfer in translational medicine through the formation of a new generation of young researchers"-ECHITAS, project No. 164/2017, PCE-Achile entitled "Addressing the complex exposome profile in hormone-dependent cancers of the breast and prostate and its influence on tumoral genome".

\section{References}

[1] Li Y, Zhao H, Huang X, Tang J, Zhang S, Li Y, Liu X, He L, Ju Z, Lui KO, Zhou B (2018). Embryonic senescent cells re-enter cell cycle and contribute to tissues after birth. Cell Res, 28: 775-778.

[2] Grammatikakis I, Panda AC, Abdelmohsen K, Gorospe M (2014). Long noncoding RNAs (lncRNAs) and the molecular hallmarks of aging. Aging (Albany NY), 6: 992-1009.

[3] Miller BF, Hamilton, KL (2017). Overview: the modulation of ageing through altered proteostasis. J Physiol, 595:6381-6382.

[4] Klaips CL, Jayaraj GG, Hartl FU (2018). Pathways of cellular proteostasis in aging and disease. $\mathrm{J}$ Cell Biol, 217:51-63.

[5] Braicu C, Cătană C, Calin GA, Berindan-Neagoe I (2014). NCRNA combined therapy as future treatment option for cancer. Curr. Pharm, 20:6565-6574.

[6] Quan H, Fan Q, Li C, Wang YY, Wang L (2018). The transcriptional profiles and functional implications of long non-coding RNAs in the unfolded protein response. Sci Rep, 8: 4981.

[7] Redis RS, Berindan-Neagoe I, Pop VI, Calin GA (2012). Non- coding RNAs as theranostics in human cancers. J Cell Biochem, 113: 1451-1459.
[8] Cătană CS, Pichler M, Giannelli G, Mader RM, Berindan-NeagoeI(2017). Non-coding RNAs, the Trojan horse in two-way communication between tumor and stroma in colorectal and hepatocellular carcinoma. Oncotarget, 8: 29519-29534.

[9] Gulei D, Mehterov N, Ling H, Stanta G, Braicu C, Berindan-Neagoe I (2017). The "good-cop bad-cop" TGF-beta role in breast cancer modulated by non-coding RNAs General subjects. Biochim Biophys Acta, 1861:1661-1675.

[10] Hartl FU, Bracher A, Hayer-Hartl M (2011). Molecular chaperones in protein folding and proteostasis. Nature, 475(7356):324.

[11] Ghanam AR, Ali W, Abdalla M(2018). Long non-coding RNA-protein interaction: the preliminary step to track their biological functions. Genetics and Molecular Research, 17(4).

[12] Schmitz KM, Mayer C, Postepska A, Grummt I (2010). Interaction of noncoding RNA with the rDNA promoter mediates recruitment of DNMT3b and silencing of rRNA genes. Genes Dev, 24(20):2264-9.

[13] Johnsson P, Ackley A, Vidarsdottir L, Lui WO, Corcoran M, Grandér D, Morris KV (2013). A pseudogene longnoncoding-RNA network regulates PTEN transcription and translation in human cells. Nat Struct Mol Biol, (4):440.

[14] Guttman M, Donaghey J, Carey BW, Garber M, Grenier JK, Munson G, Young G, Lucas AB, Ach R, Bruhn L, Yang X(2011). lincRNAs act in the circuitry controlling pluripotency and differentiation. Nature, 477(7364):295.

[15] Nakagawa S, Naganuma T, Shioi G, Hirose T (2011). Paraspeckles are subpopulation-specific nuclear bodies that are not essential in mice. J Cell Biol, 193(1):31-9.

[16] Li Z, Chao TC, Chang KY, Lin N, Patil VS, Shimizu C, Head SR, Burns JC, Rana TM (2014). The long noncoding RNA THRIL regulates TNF $\alpha$ expression through its interaction with hnRNPL. Proc Natl Acad Sci U S A, 111(3):1002-7.

[17] Faghihi MA, Modarresi F, Khalil AM, Wood DE, Sahagan BG, Morgan TE, Finch CE, Laurent III GS, Kenny PJ, Wahlestedt C (2008). Expression of a noncoding RNA is elevated in Alzheimer's disease and drives rapid feed-forward regulation of $\beta$-secretase. Nat Med, 14(7):723.

[18] Kretz M, SiprashviliZ, Chu C, Webster DE, Zehnder A, Qu K, Lee CS, Flockhart RJ, Groff AF, Chow J, Johnston D (2013). Control of somatic tissue differentiation by the long non-coding RNA TINCR. Nature, 493(7431):231.

[19] Lee SY, Hwang YK, Yun HS, Han JS (2012). Decreased levels of nuclear glucocorticoid receptor protein in the hippocampus of aged Long-Evans rats with cognitive impairment. Brain research, 1478: 48-54.

[20] Baldassarre A, Masotti A (2012). Long Non-Coding RNAs and p53 Regulation. Intl J Mol Sci, 13: 1670816717.

[21] Seles M, Hutterer GC, Kiesslich T, et al (2016). Current Insights into Long Non- Coding RNAs in Renal Cell Carcinoma. Int J Mol Sci, 17:573.

[22] Derrien T, Johnson R, Bussotti G, Tanzer A, et al (2012). The GENCODE v7 catalog of human long noncoding 
RNAs: Analysis of their gene structure, evolution, and expression. Genome Res, 22:1775-1789.

[23] Braicu C, Zimta AA, Harangus A, Iurca I, Irimie A, Coza O, Berindan-Neagoe I (2019). The Function of Non- Coding RNAs in Lung Cancer Tumorigenesis. Cancers (Basel). 11: pii: E605.

[24] Kopp F, Mendell JT (2018). Functional Classification and Experimental Dissection of Long Noncoding RNAs. Cell, 172: 393-407.

[25] Braicu C, Zimta AA, Gulei D, Olariu A, BerindanNeagoe I (2019). Comprehensive analysis of circular RNAs in pathological states: biogenesis, cellular regulation, and therapeutic relevance. Cell Mol Life Sci, 76: 1559-1577.

[26] Jariwala N, Sarkar D (2016). Emerging role of lncRNA in cancer: a potential avenue in molecular medicine. Ann Transl Med, $4: 286$

[27] Huarte M (2015). The emerging role of lncRNAs in cancer. Nat Med, 21: 1253-1261.

[28] Balch WE, Morimoto RI, Dillin A, Kelly JW (2008). Adapting proteostasis for disease intervention, Science, 319:916-919.

[29] Powers ET, Morimoto RI, Dillin A, Kelly JW, Balch WE (2009). Biological and Chemical Approaches to Diseases of Proteostasis Deficiency. Annu Rev Biochem, 78:959991.

[30] Fernandes DP, Bitar M, Jacobs FM, Barry G (2018). Long Non-Coding RNAs in Neuronal Aging. Noncoding RNA. Noncoding RNA, 4 pii: E12.2018.

[31] Ferrè F, Colantoni A, Helmer-Citterich M (2016). Revealing protein-lncRNA interaction. Brief Bioinform, 17: 106-116.

[32] He J, Tu C, Liu Y (2018). Role oflncRNAs in aging and age-related diseases. Aging Medicine. 1(2):158-75.

[33] Fawzy M, Toraih E, Abdallah H(2017). Long noncoding RNA metastasis-associated lung adenocarcinoma transcript 1 (MALAT1): A molecular predictor of poor survival in glioblastoma multiforme in Egyptian patients. Egyptian Journal of Medical Human Genetics, 18: 23123.

[34] Tripathi V, Shen VZ, Chakraborty A, Giri S, Freier SM, Wu X, Zhang Y, Gorospe M, Prasanth SG, Lal A, Prasanth, KV (2013). Long noncoding RNA MALAT1 controls cell cycle progression by regulating the expression of oncogenic transcription factor B-MYB. PLoS Genet, 9(3):e1003368

[35] Xie Z, Xia W, Hou M (2017). Long intergenic noncoding RNAp21 mediates cardiac senescence via the Wnt/ßcatenin signaling pathway in doxorubicin-induced cardiotoxicity. Mol Med Rep, 17:2695-2704.

[36] Kim C, Kang D, Lee EK, Lee JS (2017). Long Noncoding RNAs and RNA-Binding Proteins in Oxidative Stress, Cellular Senescence, and Age-Related Diseases. Oxid. Med. Cell Longev, 2017, 2062384.

[37] Hall JR, Messenger Z J, Tam H W, Phillips SL, Recio L, Smart RC (2015). Long noncoding RNA lincRNA-p21 is the major mediator of UVB-induced and p53dependent apoptosis in keratinocytes. Cell Death Dis, 6:e1700.

[38] Kurokawa R (2011). Promoter-associated long noncoding RNAs repress transcription through a RNA binding protein TLS. Adv Exp Med Biol, 722: 196-208.

[39] Filipits M, Dafni U, Gnant M, et al (2018). Association of p27 and Cyclin D1 Expression and Benefit from Adjuvant Trastuzumab Treatment in HER2-Positive Early Breast Cancer: A TransHERA Study. Clin Cancer Res, 24:3079-3086.

[40] Yap KL, Li S, Muñoz-Cabello AM, RaguzS, et al (2010). Molecular interplay of the noncoding RNA ANRIL and methylated histone $\mathrm{H} 3$ lysine 27 by polycomb $\mathrm{CBX} 7$ in transcriptional silencing of INK4a. Mol Cell, 38:662674.

[41] Zhao B, Lu YL, Yang Y, et al (2018). Overexpression of IncRNA ANRIL promoted the proliferation and migration of prostate cancer cells via regulating let$7 \mathrm{a} / \mathrm{TGF}-\beta 1 /$ Smad signaling pathway. Cancer Biomark, 21:613-620.

[42] Wu Y, Zhang L, Wang Y, et al (2014). Long noncoding RNA HOTAIR involvement in cancer. Tumour Biol, 35: 9531-9538.

[43] Cai B, Song XQ, Cai JP, Zhang S (2014). HOTAIR: a cancer-related long non-coding RNA. Neoplasma, 61: 379-391.

[44] Del Vecchio G, De Vito F, Saunders SJ, Risi A, Mannironi C, Bozzoni I, Presutti C (2016). RNAbinding protein HuR and the members of the miR-200 family play an unconventional role in the regulation of cJun mRNA. RNA, 22: 1510-1521.

[45] Yoon J H, Abdelmohsen K, Kim J, et al (2013). Scaffold function of long non-coding RNA HOTAIR in protein ubiquitination. Nat. Commun, 4: 2939.

[46] Cătană CS, Calin GA, Berindan-Neagoe I (2015). Inflamma-miRs in Aging and Breast Cancer: Are They ReliablePlayers? Front Med (Lausanne), 2:85.

[47] Özeş AR, Miller DF, Özeş ON, Fang F, Liu Y, Matei D (2016). NF-кB-HOTAIR axis links DNA damage response, chemoresistance and cellular senescence in ovarian cancer, Oncogene, 35: 5350-5361.

[48] Dasgupta P, Kulkarni P, Majid S, et al (2018). MicroRNA-203 Inhibits Long Noncoding RNA HOTAIR and Regulates Tumorigenesis through Epithelial-to-mesenchymal Transition Pathway in Renal, Cell Carcinoma. Mol Cancer Ther, 17:1061-1069.

[49] Ummanni R, Jost E, Braig M, et al (2011). Ubiquitin carboxyl-terminal hydrolase 1 (UCHL1) is a potential tumour suppressor in prostate cancer and is frequently silenced by promoter methylation. Mol Cancer, 10: 129.

[50] Carrieri C, Cimatti L, Biagioli M, et al (2012). Long non-coding antisense RNA controls Uchl1 translation through an embedded SINEB2 repeat. Nature, 491: 454457.

[51] Zhang L, Zhou Y, Huang T, et al (2017). The Interplay of LncRNA-H19 and Its Binding Partners in Physiological Process and Gastric Carcinogenesis. Int J Mol Sci, 20: 18(2).pii: E450.

[52] Liu Y, Zhao J, Zhang W, Gan J, Chengen H, Huang G, Zhang Y (2015). lncRNA GAS5 enhances G1 cell cycle arrest via binding to $\mathrm{YBX} 1$ to regulate $\mathrm{p} 21$ expression in stomach cancer. Sci Rep, 5:10159.

[53] Huang J, Mousley CJ, Dacquay L, Maitra N, et al 
(2018). A Lipid Transfer Protein Signaling Axis Exerts Dual Control of Cell-Cycle and Membrane Trafficking Systems. Dev Cell, 44:378-391.

[54] Kitagawa M, Kitagawa K, Kotake Y, Niida H, and Ohhata T (2013). Cell cycle regulation by long noncoding RNAs. Cell Mol Life Sci, 70:4785-4794.

[55] Mourtada-Maarabouni M, Pickard MR, Hedge V L, Farzaneh F GT (2009). GAS5, a non-protein-coding RNA, controls apoptosis and is downregulated in breast cancer. Oncogene, 28:195-208.

[56] Goossens J, Vanmechelen E, Trojanowski JQ, et al (2015). TDP-43 as a possible biomarker for frontotemporal lobar degeneration: a systematic review of existing antibodies. Acta Neuropathol Commun, 3:5.

[57] Hollander MC, Alamo I, Jr. Fornace AJ (1996). A novel DNA damage-inducible transcript, gadd7, inhibits cell growth, but lacks a protein product. Nucleic Acids Res, 24:1589-1593.

[58] Walter P, Blober G (1982). Signal recognition particle contains a 7S RNA essential for protein translocation across the endoplasmic reticulum. Nature, 299: 691-698.

[59] Deschênes M, Chabo B (2017). The emerging role of alternative splicing in senescence and aging. Aging Cell, 16:918-933.

[60] Cătană C S, Atanasov A G, Berindan-Neagoe I (2018). Natural products with anti-aging potential: Affected targets and molecular mechanisms. Biotechnol Adv, 36:1649-1656.

[61] Wong SQ, Kumar AV, Mills J, Lapierre LR (2019). Autophagy in aging and longevity. Hum Genet,

[62] Zhuo C, Jiang R, Lin X, Shao M (2016). LncRNA H19 inhibits autophagy by epigenetically silencing of DIRAS3 in diabetic cardiomyopathy. Oncotarget, 8:1429-1437.

[63] Gu Z, Hou Z, Zheng L, Wang X, Wu L, Zhang C (2018). LncRNA DICER1-AS1 promotes the proliferation, invasion and autophagy of osteosarcoma cells via miR-30b/ATG5, Biomed. Pharmacother, 104: 110-118.

[64] Xiong H, Li B, He J, Zeng Y, Zhang Y, He F (2017). lncRNA HULC promotes the growth of hepatocellular carcinoma cells via stabilizing COX-2 protein. Biochem. Biophys. Res Commun, 490: 693-699.

[65] Wang Y, Xu Z, Jiang J, Xu C, Kang J, Xiao L, Wu M, Xiong J, Guo X, Liu H (2013). Endogenous miRNA sponge lincRNA-RoR regulates Oct4, Nanog, and Sox2 in human embryonic stem cell self-renewal. Developmental cell, 25(1):69-80.

[66] Xin X, Wu M, Meng Q, Wang C, et al (2018). Long noncoding RNA HULC accelerates liver cancer by inhibiting PTEN via autophagy cooperation to miR15a. Mol Cancer, 17:94.

[67] Yin D, Liu Z, Zhang ZE, Kong R, Zhang Z, Guo R (2015). Decreased expression of long noncoding RNA MEG3 affects cell proliferation and predicts a poor prognosis in patients with colorectal cancer. Tumour Biol, 36: 4851-4859.

[68] Ying L, Huang Y, Chen H, Wang Y, Xia L, Chen Y, Liu Y, Qiu F (2013). Downregulated MEG3 activates autophagy and increases cell proliferation in bladder cancer. Mol Biosystems, 9: 407-411.

[69] Cui X, Jing X, Long C, Tian J, Zhu J (2017). Long noncoding RNA MEG3, a potential novel biomarker to predict the clinical outcome of cancer patients: a metaanalysis. Oncotarget, 8: 19049-19056.

[70] Abdelmohsen K, Panda A C, Kang MJ, et al (2014). 7SL RNA represses p53 translation by competing with HuR. Nucleic Acids Res, 42: 10099-100111.

[71] Yan W, Chen ZY, Chen JQ, Chen HM (2018). LncRNA NEAT1 promotes autophagy in MPTP-induced Parkinson's disease through stabilizing PINK1 protein. Biochem Biophys Res Commun, 496:1019-1024.

[72] Gu J, Wang Y, Wang X, Zhou D, Wang X, Zhou M, He Z (2018). Effect of the LncRNA GAS5-MiR-23a-ATG3 axis in regulating autophagy in patients with breast cancer. Cell Physiol Biochem, 48:194-207.

[73] Ribeiro DM, Zanzoni A, Cipriano A, et al (2018). A Lipid Transfer Protein Signaling Axis Exerts Dual Control of Cell-Cycle and Membrane Trafficking Systems. Nucleic Acids Res, 46:917-928.

[74] Park JY, Lee JE, Park JB, Yoo H, Lee SH, Kim JH (2014). Roles of Long Non-Coding RNAs on Tumorigenesis and Glioma Development. Brain Tumor Res Treat, 2: 1-6.

[75] Christofori G, Naik P, Hanahan D (1994). A second signal supplied by insulin-like growth factor II in oncogene-induced tumorigenesis. Nature, 369:414-418.

[76] Yang L, Lin C, Jin C, et al (2013). lncRNA-dependent mechanisms of androgen-receptor-regulated gene activation programs, Nature, 500:598-602.

[77] Song TF, Huang LW, Yuan Y, et al (2018). LncRNA MALAT1 regulates smooth muscle cell phenotype switch via activation of autophagy. Oncotarget, 9: 44114426.

[78] Wapinski O, Chang HY (2011). Long noncoding RNAs and human disease. Trends Cell Biol, 21:354-361.

[79] Deng Z, Cambell AE, Lieberamn PM (2010). TERRA, CpGmethylation and telomereheterochromatin:lessons from ICF syndrome cells. Cell Cycle, 9: 69-74.

[80] Cubiles MD, Barroso S, Vaquero-Sedas MI, Enguix A, Aguilera A, Vega-Palas MA (2018). Epigenetic features of human telomeres. Nucleic Acids Res, 46: 2347-2355.

[81] Gao D, Lv AE, Li HP, Han DH, Zhang YP (2017). LncRNA MALAT-1 Elevates HMGB1 to Promote Autophagy Resulting in Inhibition of Tumor Cell Apoptosis in Multiple Myeloma, J Cell Biochem, 118: 3341-3348.

[82] Hu M, Wang R, Li X, Fan M, Lin J, Zhen J, Chen L, Lv Z (2017). LncRNA MALAT1 is dysregulated in diabetic nephropathy and involved in high glucose-induced podocyte injury via its interplay with $\beta$-catenin. J Cell Mol Med, 21:2732-2747.

[83] Kotake Y, Kitagawa K, Ohhata T, Sakai S, Uchida C, Niida H., Naemura M, Kitagawa M (2016). Long non-coding RNA, PANDA, contributes to the stabilization of 553 tumor suppressor protein. Anticancer Research, 36: 1605-1611.

[84] Kotake Y, Goto T, Naemura M, Inoue Y, Okamoto H, Tahara K (2017). Long noncoding RNA PANDA positively regulates proliferation of osteosarcoma 
cells. Anticancer Research, 37:81-85.

[85] Luo G, Liu D, Huang C, Wang M, Xiao X, Zeng F (2017). LncRNAGAS5 Inhibits Cellular Proliferation by Targeting P27 ${ }^{\text {Kip1 }}$. Mol Cancer Res, 15: 789-799.

[86] Hung T, Wang Y, Lin M F, et al (2011). Extensive and coordinated transcription of noncoding RNAs within cell-cycle promoters. Nature Genetics, 43: 621-629.

[87] BeckedorffFC, Ayupe AC, Crocci-Souza R, et al(2013). The Intronic long noncoding RNA ANRASSF1 recruits PRC2 to the RASSF1A promoter, reducing the expression of RASSF1A and increasing cell proliferation. PLoS Genet, 9: e1003705.

[88] Liu X, Li D, Zhang W, Guo M, Zhan Q (2012). Long non-coding RNA gadd7 interacts with TDP-43 and regulates Cdk6 mRNA decay. EMBO J, 31: 4415-4427.

[89] Zeng S, Yang J, Zhao J, Liu Q, Rong M, Guo Z, Gao W (2014). Silencing Dicer expression enhances cellular proliferative and invasive capacities in human tongue squamous cell carcinoma. Oncol Rep, 31:867-873.

[90] Xiang JF, Yin QF, Chen T, et al (2014). Human colorectal cancer-specific $C C A T 1-L$ lncRNA regulates long-range chromatin interactions at the $M Y C$ locus. Cell Research. 24,513-531.

[91] SamperE, Flores JM, Blasco MA(2001). Restoration of telomerase activity rescues chromosomal instability and premature aging in $\mathrm{Terc}^{-/}$mice with short telomeres. EMBO Rep, 2: 800-807.

[92] Tan MC, Widagdo J, Chau YQ, et al (2017). The Activity-Induced Long Non-Coding RNA Meg3 Modulates AMPA Receptor Surface Expression in Primary Cortical Neurons. Front Cell Neurosci, 11:124.

[93] Hu G, Niu F, Humburg BA, Liao K, Bendi S, Callen S, Fox HS, Buch S (2018). Molecular mechanisms of long noncoding RNAs and their role in disease pathogenesis. Oncotarget, 9:18648-18663.

[94] Rapicavoli NA, Poth EM, Zhu HS Blackshaw (2011). The long noncoding RNA Six3OS acts in trans to regulate retinal development by modulating Six 3 activity. Neural Dev, 6: 32 .
[95] Massone S, Vassallo I, Fiorino G, et al (2011). 17A, a novel non-coding RNA, regulates GABA B alternative splicing and signaling in response to inflammatory stimuli and in Alzheimer disease. Neurobiol Dis, 41: 308-317.

[96] Barry G, Guennewig B, Fung S, et al (2015). Long NonCoding RNA Expression during Aging in the Human SubependymalZone. Front Neurol, 6:45.

[97] Stilling RM, Benito E, Gertig M, et al (2014). Deregulation of gene expression and alternative splicing affects distinct cellular pathways in the aging hippocampus. Front. Cell. Neurosci, 8:373.

[98] Salta E, De Strooper B (2017). Noncoding RNAs in neurodegeneration. Nat Rev Neurosci, 18: 627-640.

[99] Wang S, Zhang X, Guo Y, Rong H, Liu T (2017). The long noncoding RNA HOTAIR promotes Parkinson's disease by upregulating LRRK2 expression. Oncotarget, 8: 24449-24456.

[100] Riva P, Ratti A, Venturin M (2016). The Long NonCoding RNAs in Neurodegenerative Diseases: Novel Mechanisms of Pathogenesis. Curr. Alzheimer Res, 13: 1219-1231.

[101] Modarresi F, Faghihi MA, Patel NS, et al (2011). Knockdown of BACE1-AS Nonprotein-Coding Transcript Modulates Beta-Amyloid-Related Hippocampal Neurogenesis. Int J Alzheimers Dis, 2011: 929042.

[102] Kitagawa M, Kitagawa K, Kotake Y, Niida H, Ohhata T (2013). Cell cycle regulation by long non-coding RNAs. Cell Mol Life Sci, 70: 4785-4794.

[103] Collette J, Le Bourhis X, Adriaenssens E (2017). Regulation of Human Breast Cancer by the Long NonCoding RNA H19. Int J Mol Sci, 18: E 2319.

[104] MatoukIJ, Halle D, Raveh E, Gilon M, Sorin V, Hochberg A (2016). The role of the oncofetal H19 lncRNA in tumor metastasis: orchestrating the EMTMET decision. Oncotarget, 7: 3748-3765. 